\title{
Epidemiological Study on Bovine Tuberculosis in Boran Breeds Cattle at Yabello District, Southern, Ethiopia
}

\author{
Guyo Kanchora ${ }^{1,}$, , Roba Jiso ${ }^{2}$, Meseret Tsegaye ${ }^{3}$, Abraha Bisrat ${ }^{4}$ \\ ${ }^{1}$ Department of Veterinary Epidemiology, College of Computational Science, Hawassa University, Hawassa, Ethiopia \\ ${ }^{2}$ Department of Animal Science, College of Agriculture Science, Arba Minch University, Arba Minch, Ethiopia \\ ${ }^{3}$ Yabello District Livestock Resource Development Office, Yabello, Ethiopia \\ ${ }^{4}$ College of Veterinary Medicine, Mekelle University, Mekelle, Ethiopia
}

\section{Email address:}

guyokanchora@yahoo.com (G. Kanchora)

${ }^{*}$ Corresponding author

\section{To cite this article:}

Guyo Kanchora, Roba Jiso, Meseret Tsegaye, Abraha Bisrat. Epidemiological Study on Bovine Tuberculosis in Boran Breeds Cattle at Yabello District, Southern, Ethiopia. American Journal of Bioscience and Bioengineering. Vol. 8, No. 6, 2020, pp. 105-115. doi: $10.11648 /$ j.bio.20200806.12

Received: September 19, 2020; Accepted: October 5, 2020; Published: December 8, 2020

\begin{abstract}
A cross-sectional study was conducted at Yabello district, Southern Ethiopia from December 2009 to April 2010 with the aim of an epidemiological survey of Bovine tuberculosis through different diagnostic approach Comparative Intradermal Tuberculin test (CIDT), Questionnaire survey, Abattoir inspection, Bacteriological, and Histopathological examination on animals presenting in the study area. A retrospective study of human TB cases recorded at Yabello Hospital over a six-year (2004-2009) period was also analyzed to determine the significance of the extrapulmonary tuberculosis (EPTB) form of human TB in the district. During the study period, 790 heads of local Boran breed cattle were included among which 540 heads of cattle were subjected for the CIDT test, while the remaining 250 heads were subjected only for abattoir inspection. The prevalence of gross tuberculous lesion positive samples was $16.4 \%$. These samples were again collected for Ziehl Neelsen acid-fast stain and histopathological examination. The result of Ziehl Neelsen acid-fast stain has indicated that, 19.5\% positive and $80.5 \%$ negative. There was a statistically significant association between the occurrence of the lesions and body condition score (BCS) $\left(\chi^{2}=10.903, \mathrm{P}=0.006\right)$. On the other hand, the result of the CIDT test has revealed $1.3 \%$ positive, $7.2 \%$ suspected, and $91.5 \%$ negative. All selected traits (sex, Age. BCS, and origin of the animal) measured with the PPD test did not show a statistically significant difference among the categories ( $p>0.05$ ). Besides, a questionnaire survey conducted on 23 households of animal owners indicated that $95.7 \%$ had the habit of raw milk consumption. A retrospective study of human TB cases recorded for six years revealed that there was a $13.76 \%$ proportion of EPTB forms. The prevalence of BTB in the study area is slightly high when compared with the previous study. However, it needs further investigation and surveillance to explore the control and prevention methods of BTB and its zoonotic importance which requires the awareness of the population on the management of the disease and associated risk factors.
\end{abstract}

Keywords: Abattoir, Acid-fast, Bovine TB, Borana, Ethiopia

\section{Introduction}

Bovine Tuberculosis (BTB) was widespread in many European countries and is a public health concern in some developing countries [1]. It is a chronic bacterial disease of animals, wildlife, and humans and is caused by Mycobacterium bovis (M. bovis), which belongs to a group of mycobacteria known as Mycobacterium tuberculosis complex (MTBC) [2]. M. bovis has one of the broadest host ranges of all known pathogens and has been diagnosed worldwide [1]. The distribution of the disease and its prevalence in various countries can be obtained from sources such as world animal health compiled by the Office of International des Epizooties (OIE) an ongoing basis and others [3].

Bovine tuberculosis is usually characterized by the 
formation of nodular granulomas known as tubercles and they are most frequently observed in several tissues, even though they are frequently seen in lymph nodes at the head and neck, lung, intestines, liver, and pleural cavity. Extreme emaciation and acute respiratory distress may occur during the terminal stages of the disease. The Rates of M. bovis infection is higher among closely confined animals than animals in extensive farming systems This disease is one of the seven most neglected endemic diseases in the world, particularly in developing countries, and is a significant zoonosis that can spread to humans through aerosols, by the consumption of unpasteurized milk and dairy products and through meat from infected cows Veterinarians, farmers, and abattoir workers were most considered at the risk of this disease. The disease induces high animal morbidity and mortality that eventually reduces the financial capital and increases production costs [4].

The epidemiology of $\mathrm{M}$. Bovis was described by numerous authors in extensive detailed reviews, however, they tend to focus mainly on experiences from industrialized countries, where control and/or eradication programmed have been implemented for a long time. Although cattle are considered to be the main hosts of M. Bovis, the disease has been reported in many other species, including humans, other domesticated animals, and wildlife [5]. Infectious animals shed M. bovis via milk, saliva, feces/urine, and discharging lesions [6]. It is generally accepted that human beings get infected either by inhalation of bacteria containing dust particles and aerosols shed by infected animals or by ingestion of contaminated animal products (e.g., raw milk). The main route of infection in cattle is through aerosol exposure, facilitated by close contact between animals. In cattle, the ingestion of contaminated products (e.g., pasture and water) is generally considered to be a secondary, less important route of transmission [7]. A high prevalence of $\mathrm{M}$. Bovis was found in a recent abattoir survey in Chad in culture-positive mammary glands and young tuberculin-positive animals. Isolated M. Bovis in milk and feces from milking buffaloes and cattle in Nepal indicates that transmission to young animals by milk should not be neglected. Recent publications from Africa also suggest that the ingestion of $\mathrm{M}$. Bovis might be an important mode of disease transmission in cattle since mesenteric lymph nodes were shown to be more affected than mediastinal lymph nodes [8]. Therefore, the contaminated environment might also play a bigger role in the epidemiology of BTB than assumed until now, thus showing that our understanding of the epidemiology of M. Bovis in sub-Saharan Africa is still limited.

In Ethiopia, isolation of M. bovis was done mainly from domestic animal species and humans. In cattle, most of the studies conducted on Bovine TB so far have been focusing on the highlands of Central Ethiopia while a lot of areas especially the pastoral lowlands are not covered by adequate studies. The distribution of the disease varies from place to place based on the production systems under which livestock are managed [9]. A Preliminary study was conducted in
Adama Municipality Abattoir from October 2002- April 2003 to estimate the prevalence found to be $5.15 \%$ based on postmortem examination and comparative intradermal test (CIDT) [10]. In Addition to this bovine tuberculosis is more prevalent in cattle owned by farmers with active tuberculosis in central Ethiopia. According to this research evident of 87 patients with TB. $63(72 \%)$ and $24(28 \%)$ were diagnosed as pulmonary and extrapulmonary $\mathrm{TB}$, respectively. Of all TB patients, about $84 \%(73 / 87)$ was as consuming raw milk and milk products. while only $7 \%(6 / 87)$ were consume boiled milk regularly the remaining $9 \%(8 / 87)$ reported that they did not consume milk at all [11].

In recent years it has come evident that infection with Mycobacterium Bovis, the cause of the infection in cattle is common in a wide variety of wildlife in various parts of the world. The infection in wildlife is important not only from the perspective of the value of some species of world life. Some of which are endangered, but because of the role that wildlife maintenance hosts of the disease can play in sustaining the infection in domestic stock [5].

In developing countries, the occurrence of human tuberculosis due to M. bovis particularly in Africa represents a potential health threat to both humans and animals. This is mainly because closely $82 \%$ of the human and $85 \%$ of cattle population live in regions where BTB is highly prevalent. Studies showed that BTB is still common in these developing countries where routine milk pasteurization is not practiced, and an estimated $10-15 \%$ of human tuberculosis incidences are because of M. bovis [12]. Around 9 million new cases of TB and 2 million deaths are reported worldwide annually, with sub-Saharan Africa displaying the highest annual risk of infection with TB, probably catalyzed by the HIV/AIDS pandemic [13]. In industrialized countries, animal TB control and elimination programs, together with milk pasteurization, have drastically reduced the incidence of disease caused by M. bovis in both cattle and humans. In developing countries, however, animal TB is widely distributed, control measures are not applied or are applied sporadically, and pasteurization is rarely practiced. The direct correlation between M. bovis infection in cattle and disease in the human population has been well documented in industrialized countries. Whereas little information is available from developing countries (, risk factors for M. Bovis in both animals and humans are present in the tropics [14].

Mycobaterium bovis is also the most frequent cause of zoonotic tuberculosis (TB) in humans [15]. Tuberculosis, which is primarily a respiratory disease, is responsible for the death of more people each year than any other infectious disease. The World Health Organization (WHO) reported 9.2 million new cases of human TB and 2 million deaths in 2006, with Sub-Saharan Africa having the highest annual risk of infection with tuberculosis, probably aggravated by the expanding Human Immunodeficiency Virus (HIV) epidemic and increasing drug resistance [16].

In Ethiopia, the pastoral production system herds are reared for seasonal milk and meat productions under traditional animal husbandry practice with low hygienic 
standards. In this production system drinking raw milk is a common practice, in rural areas in particular, which may expose the community to contagious diseases most notably Bovine TB. Unpasteurized raw milk is preferably consumed than boiled milk in the Ethiopian community mainly because of its accessibility, convenience, good taste, and lower price. The public health threat of BTB is mainly associated with the consumption of unpasteurized dairy products having $\mathrm{M}$. bovis [18]. Close contact between animals and humans is also considered as a potential risk factor for the disease [19].

Recently, Regassa [20] demonstrated the association of M. tuberculosis and M. bovis in causing tuberculosis between humans and cattle. The cattle owned by tuberculosis patients had a higher prevalence $(24.3 \%)$ than cattle owned by non-tuberculosis owners with $8.6 \%$. The author also noted that $73.8 \%$ and $16.7 \%$ of 42 human isolates were identified as M. tuberculosis and M. bovis and from cattle isolates $18.1 \%$ and $45.5 \%$ of 11 were found to be M. tuberculosis and M. bovis species, respectively. This showed that the role of $\mathrm{M}$. bovis in causing human tuberculosis seemed to be significantly important. On the other hand, in Ethiopia, consuming raw meat is a welcome tradition, thus meat may also remain to be another area of concern or threat to be a source of BTB infection.

Borana is one of the pastoral communities in Ethiopia that, their livelihood depends on animal and animal products. Although these communities are known by their diversified livestock and play a role to others by supplying /distributing market-oriented animals for most regions of the country and export abattoirs, satisfactory research has not been done concerning BTB to assess awareness of cattle owners about BTB and its transmission and conducted their study on BTB by abattoir inspection only. So, based on these situations, this study on BTB in the study area using the CIDT test, questionnaire survey, and routine abattoir inspection will give a clue for further study and development of control and prevention strategies [21, 22].

Therefore, the objectives of this study were:

1) To make an epidemiological assessment on the prevalence of BTB in different sites of the study area.

2) To assess the relationship of tuberculosis infection with possible risk factors and its public health importance in the study area by looking at records of relevant medical posts.

\section{Materials and Methods of Study}

\subsection{Study Area}

The study was conducted from December 2009 to May 2010, in Yabello district (Dida Tuyura Ranch, Some selected PA in the district and Yabello Municipal Abattoir) Borena Zone. Yabello is town and seat of administrative bodies of Borena Zone, which is $565 \mathrm{~km}$ far from Addis Ababa. Approximately more than 35,000 human populations present in it. The Borena Zone (Southern Rangeland) covering an area of about 160,000 square kilometers and accounting for up to
$13 \%$ of the total land area of Ethiopia, was considered until a few decades ago, as the finest grazing land in East Africa [23]. The numbers of livestock of the zone on the basis of species are 1,496,652 cattle,452,177 goats,193,021 sheep,106,366 camels,355,700 chickens, 13,945 mules,61,699 donkeys [20, 24].

The vast land of the area is lowland and has a "kola" climatic condition, it gets marked variable rainfall. which receives mean annual precipitation ranging from 450-650mm often in the bimodal pattern: with long rainfall 70\% "ganna" rains expected between March-May and short rainfall 30\% "Hagayyaa" rains expected between October-November [25]. The altitude of rangeland ranges from $500-2500 \mathrm{~m}$ above sea level and the average temperature ranges from $18-28^{\circ} \mathrm{C}$ [24].

Dida Tuyura Ranch was established in 1979 by the Ethiopian Ministry of Federal Agriculture on an area covering 36 square kilometers with the following objectives: To achieve Boren breed genetic conservation, Genetic extension promotion and distribution to pastoralist community, the Demonstration site for different institutions and to support researchers from different academic level. Different wildlife like zebra, monkey, warthog, swine (pig), kaka (endemic bird), etc. also inhabited in the Ranch.

Yabello Municipal Abattoir: Yabello Township has one municipal abattoir and about 12 legally registered butcheries. Only cattle are slaughtered at the premise whereas small ruminants slaughtered in the backyard manner everywhere. Each day an average of 7 heads of cattle are slaughtered in the abattoir starting from 5:30 A. M local time. A technician conducts ante mortem examination of cattle a day before the slaughter. Sanitary and working facilities such as water supply, sinks of effluent, electricity, the slaughterhouse firm are absent. Therefore, animals are slaughtered in the fenced open, at a place allocated by the municipality.

At the abattoir, animals are routinely bled by cutting the jugular vein after casting with a rope; dressing is carried out manually on the ground. There is no record for pathological lesion encountered but the total number of cattle inspected at the abattoir is reported. Horse carts are used to transport the carcass, so the hygienic condition and handling of the carcass are very poor.

Laboratory work was conducted in the National Animal Health Diagnostic and Investigation Center for microbiology and histopathology study.

\subsection{Study Population}

A cross-sectional study was conducted to make an epidemiological survey of the prevalence of Bovine tuberculosis in Dida Tuyura Ranch, two selected PA in Yabello woreda, and in Yabello Municipal Abattoir from December 2009 to May 2010. The study was carried out on 790 heads of cattle, among these 540 animals tested with Comparative Intradermal Tuberculin test (CIDT) and the rest 250 were on routine post mortem abattoir inspection for the finding of tubercle bacilli lesion. The animals were originated mainly from Yabello District, but for the abattoir, the sources 
of cattle were Yabello, Dire, Adama, and Negele Borana. Most animals belong to Boran breed, one of the best dual-purpose breeds, managed under the pastoral production system featured by communal grazing land. There is no extra feed supplement, except during harsh and long-standing drought where animals, especially those maintained at home, "loon warra" are provided with cut grasses or allowed to graze in the reserved communal plot of lands, known as "kalo". Since there is inadequate veterinary service, the tuberculosis of slaughtered cattle or the general population is not known for a long period before who reported the prevalence of Bovine tuberculosis $4.2 \%$ of cattle slaughtered in Yabello Municipal Abattoir [21].

\subsection{Sample Size}

The required sample size for this study was estimated by taking $50 \%$ of the expected prevalence. The sample size was calculated to be a minimum of 384 considering $95 \%$ confidence and $5 \%$ of desired absolute precision [26]. Although the estimated sample size was 384 , the total numbers of study cases were raised to 790 to increase the accuracy of the prevalence.

\subsection{Study Protocol}

\subsubsection{Comparative Intradermal Tests (CIDT)}

The comparative intradermal tuberculin test was conducted on 540 cattle using both avian and bovine purified protein derivates (PPD) supplied by the NAHDIC. Intradermal injections of $0.1 \mathrm{ml}(2500 \mathrm{IU} \mathrm{ml}-1)$ bovine PPD and $0.1 \mathrm{ml}(2500 \mathrm{IU} \mathrm{ml}-1)$ avian PPD were administered in two shaved sites, $12 \mathrm{~cm}$ apart from each other in the middle neck region, after having recorded initial skin thickness with a caliper and recorded as A1 for avian PPD site and B1 for bovine. One site was injected with an aliquot of $0.1 \mathrm{ml}$ of 2,500 IU/ml PPD bovine toward the head and the other site was similarly injected with $0.1 \mathrm{ml}$ of $2,500 \mathrm{IU} / \mathrm{ml} \mathrm{PPD}$ avian in dermis toward the shoulder of the animal. Final skin thickness was measured at both injection sites after $72 \mathrm{hr}$ and recorded as A2 avian PPD and B2. The results were interpreted according to the recommendation of the Office of International des Epizooties [27]. When the change in skin thickness was greater at the avian PPD injection site, the animal was considered as positive for Mycobacterium species other than the mammalian type (M. tuberculosis and M. Bovis). When increase observed at both sides of injection the difference was considered between the two sites of injections thus if the increase in skin thickness at the injection site for bovine PPD (B) was greater than the increase in skin thickness at the injection site of avian PPD (A), the manipulation of the change was done as this manner by subtracting A from B. When the change is recorded as less than $2 \mathrm{~mm}$ it should be considered as negative, between $2 \mathrm{~mm}$ and $4 \mathrm{~mm}$ suspected and equal to $4 \mathrm{~mm}$ and/or above positive for bovine tuberculosis [27]. The same person conducted the entire process of tuberculin testing and reading of the result to avoid bias related to injection and reading technique [28].

\subsubsection{Antemortem Inspection of the Live Animal}

This was preceded while the animals at resting sites /quarantine stations before submitted to the slaughterhouse. During this time the body condition, history of the animals \& its origin, age grouping, breed, and other characterization tasks were performed. Superficial lymph nodes were palpated for any swelling.

\subsubsection{Post Mortem Examination}

Routine inspection for the detection of tuberculosis lesions at the abattoir is conducted according to the method developed by the Meat Inspection and Quarantine Division of the Ministry of Agriculture and this involves visual examination and palpation of intact organs such as the liver, kidneys, lungs, and lymph nodes [29]. On the other hand, these were palpated and incised for the investigation of gross pathological lesions. Each lobe and tissue was then sectioned by using separate surgical blades if lesions are detected in one of them into about $4 \mathrm{~mm}$-thick slices to facilitate the detection of lesions. The cut surfaces were examined visually under an available light source for the presence of abscesses, calcifications, cheesy masses, and tubercles [30]. When gross lesions suggestive of BTB were found in any of the tissues examined, then collected and preserved by ice and 10\% formalin for bacteriology and histopathology studies respectively and tissues subjected to bacteriological and histopathological examination were confirmed in the National Animal Health Diagnostic and Investigation Center laboratory.

\subsubsection{Acid-fast}

Based on the acid-fast stain, acid-fast bacteria are capable of resisting decolonization with acid-alcohol and retain the primary dye (basic fuchsin), but nonacid fast bacteria are easily decolorized and retain the counterstain. These properties of acid fastness or acid alcohol fastness of stained bacilli depend on the amount and the spatial arrangement of mycolic acid and their ester in the bacterial cell wall. The chemical composition of the cell wall is dominated by complex lipids, which include glycolipid, peptidoglycolipids, lipopolysaccharides, lipoproteins, and wax [31].

\subsubsection{Histopathological Examination}

This method of diagnosis was performed on tissues suspected of tuberculous lesions obtained from animals slaughtered at Yabello Municipal Abattoir. The examination was conducted by observing and thoroughly detection of gross-lesion found on visceral organs especially the lungs, liver, Lymph nodes (mediastinal or mesenteric), and other related organs. Tissue suspected of tuberculosis lesions obtained from routine abattoir inspection was cut into smaller pieces, fixed in $10 \%$ buffered formalin for $24 \mathrm{hrs}$, dehydrated in alcohol, cleared with xylene and infiltrated in paraffin wax (melting point $60-70^{\circ} \mathrm{C}$ ), sectioned of 5 micrometer thick were cut and stained with routine Hematoxylin and Eosin [32]. 


\subsubsection{Questionnaire Survey on Cattle Owners}

Cattle owners were interviewed (Annex 7) according to their willingness to participate and after verbal consent on the same day that their cattle were tested for BTB. The open questions were focused on livestock husbandry/management, determining the respondent's awareness about transmission of tuberculosis from cattle to humans and vice versa, the recent history of tuberculosis cases in the family, and, if present, the type of tuberculosis, mixing of cattle and other livestock at night, cattle housing at night, sanitation \& ventilation of the house/barn, the purpose of the farm products, cattle contact with other cattle herds and purchasing/selling of animals. Furthermore, questions related to habits of milk and meat consumption for humans, contact between humans and cattle, knowledge of BTB, and known TB status in the household were also asked. A household was considered positive for TB if at least one member in the last 3 years had been diagnosed with pulmonary TB or showed clinical signs of EPTB (e.g., cervical lymphadenitis). Local names were used for all scientific terms during the interview.

Additionally, a six-year (2004-2009) data of human tuberculosis cases admitted to Yabello Health Center was included in the retrospective study to assess the status and trend of extrapulmonary TB in the local population.

\subsection{Data Analysis}

Data entry was done using Microsoft Office Excel and processed using SPSS version 17th statistical software after importing the data from Microsoft excel. Descriptive statistics were computed for all the parameters. Chi-square (Fischer's exact tests) was used to analyze the differences in positivity between the sexes, ages, origin, and body condition score. A p-value of less than 0.05 was considered to be statistically significant.

\section{Results}

\subsection{Result of CIDT (PPD A \& B) Antigen Tested Animals}

The comparative intradermal tuberculin (CIDT) test involves the intradermal injection of tuberculin, purified protein derivatives (PPDs) from Mycobacterium Bovis, and Mycobacterium avium, and the subsequent detection of swelling and indurations at the injection site $72 \mathrm{hr}$. later, depending on OIE recommended cutoff value of $>4 \mathrm{~mm}$. Using CIDT test criteria, $1.3 \%(7 / 540)$ animals were PPD test positive, 7.2\% (39/540) suspected and 91.5\% (494/540) were negative. Among these animals 315 were females and the rest 225 were males. As a principle, PPD test doubtful animals retested after six weeks but due to time constraints and shortage of budget, this was not conducted in those PPD tests suspected animals. As can be seen, form (Table 1) results have shown that a higher percentage (3.2\%) of which positive was obtained on the animals with poor body condition score. Risk factors (age, sex, body condition score, and origin of animals) measured about the tuberculin test did not show a statically significant difference among the categories (Table 1).

Table 1. Result of CIDT (PPD A\&B) Antigen Tested Animals in Yabello District.

\begin{tabular}{|c|c|c|c|c|c|c|c|}
\hline \multirow{2}{*}{ Variable } & \multirow{2}{*}{ Categories } & \multirow{2}{*}{ No of animals } & \multicolumn{3}{|c|}{ No of PPD examined animals (Bovine) } & \multirow{2}{*}{$\chi^{2}$} & \multirow{2}{*}{ p-value } \\
\hline & & & Positive & Negative & Doubtful & & \\
\hline \multirow{2}{*}{ Sex } & Male & 225 & 3 & 202 & 20 & \multirow{2}{*}{1.578} & \multirow{2}{*}{0.209} \\
\hline & Female & 315 & 4 & 292 & 19 & & \\
\hline \multirow{3}{*}{ Age } & $<3$ & 118 & 2 & 108 & 8 & \multirow{3}{*}{0.993} & \multirow{3}{*}{0.319} \\
\hline & $3-6$ & 344 & 4 & 318 & 22 & & \\
\hline & $>6$ & 78 & 1 & 69 & 9 & & \\
\hline \multirow{3}{*}{$\mathrm{BCS}$} & Good & 92 & 0 & 87 & 5 & \multirow{3}{*}{0.657} & \multirow{3}{*}{0.418} \\
\hline & Medium & 417 & 6 & 379 & 32 & & \\
\hline & Poor & 31 & 1 & 28 & 2 & & \\
\hline \multirow{2}{*}{$\begin{array}{l}\text { Origin of } \\
\text { animals }\end{array}$} & Ranch & 278 & 2 & 260 & 16 & \multirow{2}{*}{2.54} & \multirow{2}{*}{0.111} \\
\hline & Yabello area & 262 & 5 & 234 & 23 & & \\
\hline
\end{tabular}

Table 2. Distribution and Frequency of Lesions in Different Organs and /or Tissue From 56 Samples Collected From Animals Slaughtered at Yabello Abattoir.

\begin{tabular}{lll}
\hline Organs inspected & Frequency of tubercle lesion positive organs & (\%) \\
\hline Prescapular lymph node & 5 & 8.90 \\
Retro bronchial & 7 & 12.50 \\
Mesenteric & 12 & 21.40 \\
Mediastinal & 15 & 26.80 \\
Retropharyngeal & 3 & 5.40 \\
Lung & 8 & 14.3 \\
Liver & 2 & 3.60 \\
Intestine wall & 4 & 7.10 \\
Total & 56 & 100 \\
\hline
\end{tabular}




\subsection{Result of Routine Post Mortem Abattoir Inspection}

Based on the post mortem examination conducted on 250 heads of cattle, the prevalence of gross tuberculous lesion during routine abattoir inspection was $16.4 \%$. The lesions were found in different forms with different sizes in various organs. The organ level distribution of the lesion is indicated in (table 2). But no tuberculous lesions were found on the carcass and heart muscle during abattoir inspection.

\subsection{Result of Ziehl-Neelsen Acid Fast Stain (Microscopic Examination)}

From cattle slaughtered at Yabello Municipal Abattoir samples of 41 cattle that contain tuberculous lesions and suspected were sent to the National Animal Health Diagnostic and Investigation Center (NAHDIC) laboratory for acid-fast stain to check for the presence of acid-fast bacilli organisms. After direct Ziehl- Neelsen acid-fast staining technique performed, 19.5\% (8/41) were acid-fast positive (Figure 1), and the remaining $80.5 \%$ (33/41) smear fails to retain Carbolfuchsin.

Table 3. Association of AFS with various risk factors of animals slaughtered in Yabello Municipal Abattoir.

\begin{tabular}{|c|c|c|c|c|c|c|}
\hline \multirow{2}{*}{ Variables } & \multirow{2}{*}{ categories } & \multirow{2}{*}{ Total examined } & \multicolumn{2}{|c|}{ № of AFS examined Animals } & \multirow{2}{*}{$\chi^{2}$} & \multirow{2}{*}{ p-value } \\
\hline & & & negative & positive & & \\
\hline \multirow{2}{*}{ Age } & 2-6 year & 15 & 13 & 2 & \multirow{2}{*}{0.601} & \multirow{2}{*}{.687} \\
\hline & $>6$ year & 26 & 20 & 6 & & \\
\hline \multirow{3}{*}{ BCS } & Good & 10 & 10 & 0 & \multirow{3}{*}{10.903} & \multirow{3}{*}{.006} \\
\hline & Medium & 29 & 23 & 6 & & \\
\hline & Poor & 2 & 0 & 2 & & \\
\hline Management & Small scale fattening & 21 & 17 & 4 & 0.006 & 1.00 \\
\hline \multirow{2}{*}{ Location } & High land & 21 & 16 & 5 & \multirow{2}{*}{0.511} & \multirow{2}{*}{.697} \\
\hline & Low land & 20 & 17 & 3 & & \\
\hline
\end{tabular}

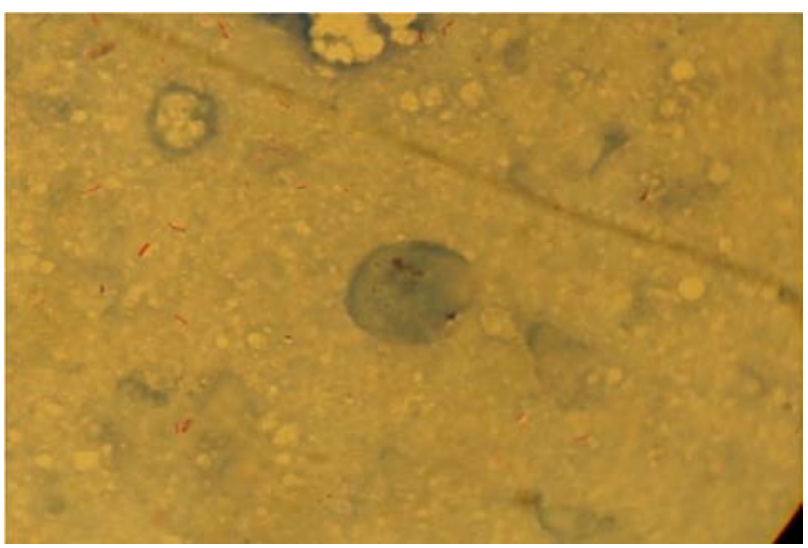

Figure 1. Acid-fast Bacilli Mycobacterium species from the sample contains the tuberculous lesion.

\subsection{Histopathological Characterization of Gross Lesions}

25 Samples, including that of AFB positive, stained with an $\mathrm{H} \& \mathrm{E}$ staining technique. During this special attention given to those samples AFB positives and that contains tuberculosis lesions to determine the histopathological characterization of the tissues. Most of the tissues suspected of granulomatous lesions contain characteristic changes of granuloma. Granulomas of varying size, predominantly consisting of aggregated epithelioid macrophages, were found in most of the organs and tissues examined and were consistently present in the lymph nodes and lungs. The developing necrotic focus was surrounded by granulation tissue, lymphocytes, and pathognomonic tubercle established. Macrophages on the wall of capsule formation by surrounding the affected part of tissues and the giant cells were developed. On these specified slides (Figure 2) there were Langrhan's types of giant cells, due to advanced cases. These large cells with several eccentric nuclei and are formed by the fusion of macrophages. This admixture of epithelioid and giant cells forms young tubercles.

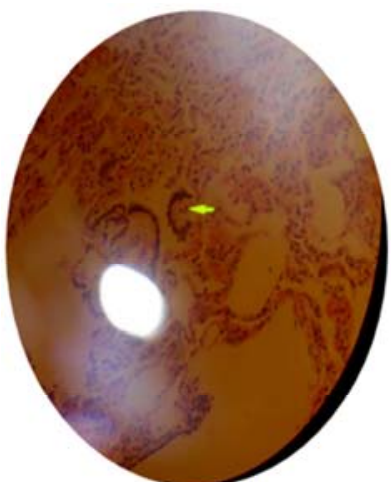

(a)

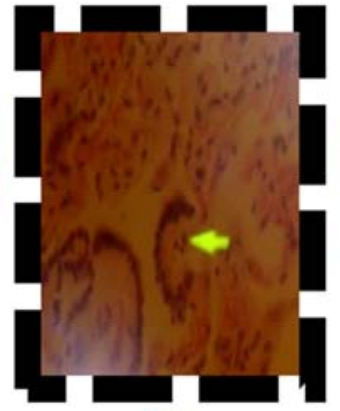

(b)

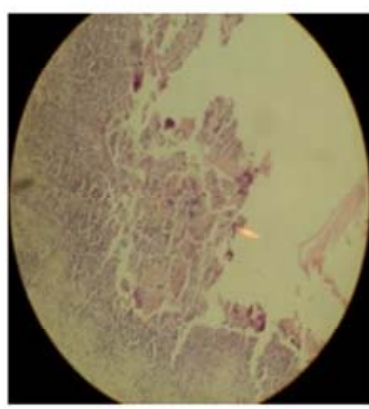

(c)

Figure 2. $(a, b \& c)$ : Macrophages and developing epithelioid Langerhans types of giant cells by surrounding granulomatous lesion from histopathology slides $H \& E$. 


\subsection{Result of Human Tuberculosis in Yabello Health Center and Its Surrounding}

Out of 1170 human TB cases registered from 2004-2009 G. C, 1009 (86.24\%) had PTB and 161 (13.76\%) suffered from EPTB (Figure 1). The trend of TB incidence in the last six years in both cases showed fluctuation from year to year. As can be seen by (Table 4) about $13.76 \%$ of tuberculosis patients admitted to Yabello Heath Center, were affected by the extrapulmonary form of the disease that a great proportion of which might have been caused by M. Bovis.
Table 4. Prevalence of tuberculosis in patients admitted to Yabello Health Center.

\begin{tabular}{llll}
\hline Year & Total & PTB & EPTB (\%) \\
\hline 2004 & 188 & 162 & $26(13.8)$ \\
2005 & 105 & 94 & $11(10.5)$ \\
2006 & 142 & 114 & $28(19.7)$ \\
2007 & 160 & 135 & $25(18.5)$ \\
2008 & 355 & 306 & $49(13.8)$ \\
2009 & 220 & 198 & $22(10)$ \\
Total & 1170 & 1009 & $161(13.76)$ \\
\hline
\end{tabular}

Source: Yabello Health Center in 2004-2009

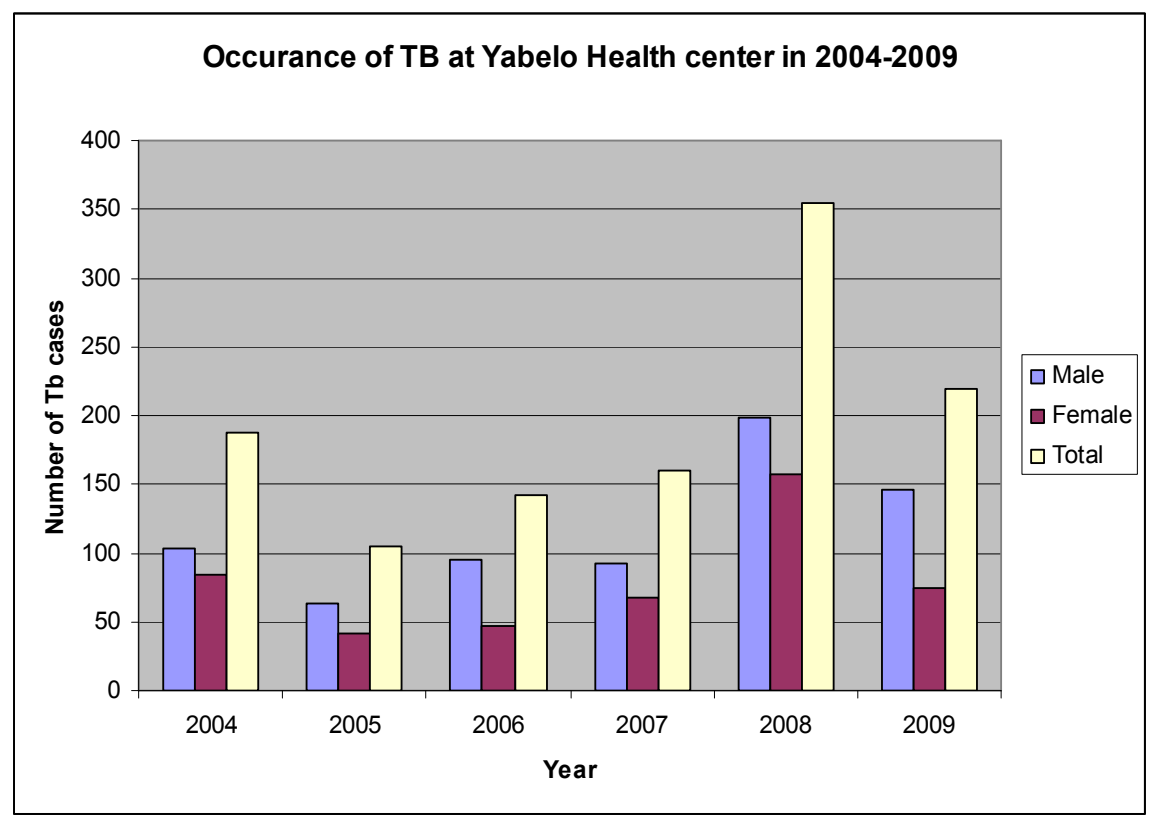

Figure 3. Trends of all forms of TB cases registered in Yabello Health Center, Borena Zone in the last six years.

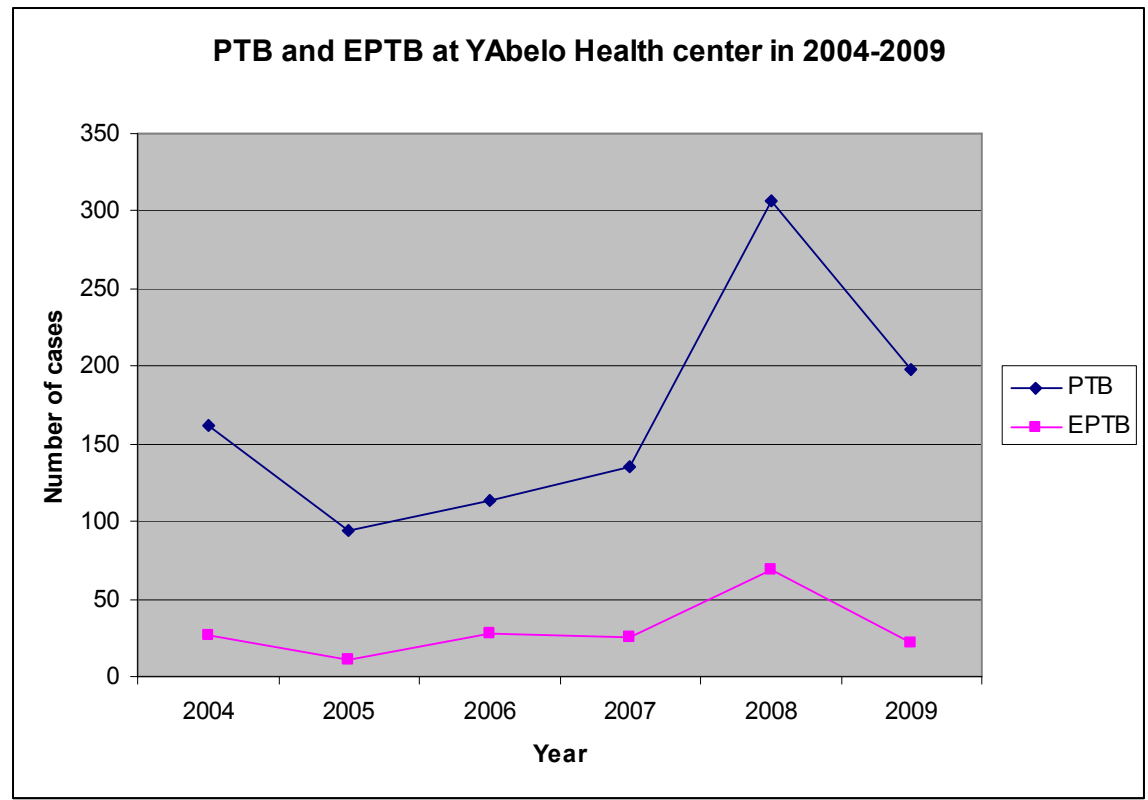

Figure 4. Trends of pulmonary and extrapulmonary TB cases for the last six years in Yabello Health Center, Borena Zone. 


\subsection{Result of Questionnaire Survey}

The result of interviews (Table 5) indicated that $52.2 \%$ $(12 / 23)$ of the households had experienced cases of human tuberculosis of the family within 3 years, of which $56.5 \%$ 13/23) owned a herd with chronic cough. But $47.8 \%(11 / 23)$ households owned animals without chronic cough still, with tuberculosis.

Concerning about habit of milk consumption, the questionnaire survey showed that, $95.7 \%(22 / 23)$ household heads had the habit of raw milk consumption. Only $4.3 \%$ $(1 / 23)$ of household heads responded that they did not consume raw milk. Regarding meat consumption, 39\% (9/23) and $61 \%(14 / 23)$ of the respondents consumed raw meat. Assessment of the knowledge of cattle owners about BTB showed that $43.5 \%$ of the respondents knew that cattle can have tuberculosis, and recognized that BTB is zoonotic, but they did not know how to prevent it.

Table 5. Knowledge of cattle owners about BTB and its transmission to humans.

\begin{tabular}{|c|c|c|c|c|c|c|c|c|c|c|c|c|}
\hline \multirow[t]{2}{*}{ Statements } & \multicolumn{2}{|c|}{$\begin{array}{l}\text { An animal with a } \\
\text { Chronic Cough }\end{array}$} & \multicolumn{2}{|c|}{$\begin{array}{l}\text { Family use raw } \\
\text { milk }\end{array}$} & \multicolumn{2}{|c|}{$\begin{array}{l}\text { Family use raw } \\
\text { meat }\end{array}$} & \multicolumn{2}{|c|}{ Know BTB } & \multicolumn{2}{|c|}{$\begin{array}{l}\text { Know BTB } \\
\text { zoonosis }\end{array}$} & \multicolumn{2}{|c|}{$\begin{array}{l}\text { The family had TB } \\
\text { in } 3 \text { years }\end{array}$} \\
\hline & $\mathrm{N}$ & $\%$ & $\mathrm{~N}$ & $\%$ & $\mathrm{~N}$ & $\%$ & $\mathrm{~N}$ & $\%$ & $\mathrm{~N}$ & $\%$ & $\mathrm{~N}$ & $\%$ \\
\hline Yes & 13 & 56.5 & 22 & 95.5 & 9 & 39 & 10 & 43.5 & 10 & 43.5 & 12 & 52.2 \\
\hline No & 10 & 43.5 & 1 & 4.3 & 14 & 61 & 13 & 56.5 & 13 & 56.5 & 11 & 47.8 \\
\hline Total & 23 & & 23 & & 23 & & 23 & & 23 & & 23 & \\
\hline
\end{tabular}

\section{Discussion}

In this study, the CIDT test conducted revealed 1.3\% individual animal prevalence. This finding highly consistent with previous reports of $1.48 \%$ by in Addis Ababa dairy farms by the same test and also with another African country in Tanzania, found individual cattle prevalence of $1.3 \%$ and $0.9 \%$, respectively using CIDT test $[4,33,35]$. However, the CIDT test prevalence shown in this study is low compared to previous results published from central Ethiopia, where prevalence $7.9 \%$ and $11.6 \%$ were observed in local zebus, using a $4 \mathrm{~mm}$ cut-off and a recent study in the Yabello area based on CIDT showed $5.5 \%$ prevalence in extensive pastoral production system $[7,9]$. This suggests that BTB epidemiology in rural extensive systems very likely differs from peri-urban livestock production systems (central Ethiopia) in the country. This might be explained by different husbandry practices and a higher number of cross-breeds and exotic breeds, considered to be more susceptible to BTB found in peri-urban settings [36].

The absence of significances in infection rates based on sex, age, body condition score (Table 1) that is consistent with previous reports. This indicates the presence of other factors that may play a significant role in the spread of tuberculosis in this study area. This may correlate with the presence of an interface between domestic and wildlife animals in this district, which uses the same grazing area and drinks from the common water point $[21,37]$. This might be considered as one of the risk factors for BTB, which consistent with the widespread distribution of $\mathrm{M}$. bovis in farm and wild animal populations represents a large reservoir of these microorganisms [38]. The spread of the infection from affected to susceptible animals both industrialized and developing countries is most likely to occur when wild and domestic animals share pasture or territory. Well documented examples of such spread include infection in badgers (Meles meles) in the United Kingdom and possums (Trichosurus vulpecula). Wild animals $\mathrm{TB}$ represents a permanent reservoir of infection and possess a serious threat to control and eliminations program [39].

The wildlife acts as major maintenance hosts in many parts of the world. Several other mammals play an important role in transmission (risk factor) at the wildlife /livestock interface, particularly those species that can easily cross fences such as Warthogs, Hyena, Zebra, and Greater kudu have the potential to act as reservoir hosts [39, 40]. However, the previous reports by other researchers on cattle the prevalence of BTB showed an increase with age [41].

In the present study, gross tuberculous lesions were found most frequently in mediastinal lymph node $(26.8 \%)$ and mesenteric lymph node (21.4\%), followed by lung tissue $(14.3 \%)$. This finding is consistent with previous reports, and may indicate infection by aerosol route as well as through the ingestion of contaminated pasture/water $[37,43,44]$. In contrast to this, other studies reported that lymph nodes of the head as being the most frequently infected tissue [45]. The prevalence of gross tuberculous lesion during routine abattoir inspection $16.4 \%$ in this study accords with the previous finding of who reported the prevalence of BTB in cattle slaughtered in Jinka Municipal Abattoir 15.4\% based on post-mortem examination [46].

In this study $\mathrm{ZN}$ acid, fast stain confirmed, out of 41 samples of animals slaughtered and diagnosed in NAHDIC laboratory, $19.5 \%(8 / 41)$ were positive and $80.5 \%(33 / 41)$ negative for AFS, respectively. From this, it can be concluded that the prevalence of BTB found in animals slaughtered in Yebello Municipal Abattoir is greater than the prevalence of PPD tested animals in the study areas. This may be due to different management systems of animals. This finding agreed with the long-held view [40].

The presence of a statically significant difference (Table 3 ) in body condition score $\left(\chi^{2}=10.903, p=0.006\right)$ indicates, poor body condition aggravates animal easily to $M$. bovis over previous confirmed that animals with poor body condition and nutritional deficiency have reduced immune resistance to bovine tuberculosis, but cattle with good nutritional supplement have well-developed body condition and high 
immune resistance easily overcome the antigen enter their cells and inhibit the further spread of the disease occurrence $[46,47]$. In other words, poor body condition may be due to the disease presence, that animals can decrease body condition. Another finding in this study is that there was no statistically significant difference in infection rate among animals managed under the ranching system and extensive pastoral around Yabello in contrast to the long-held view [40].

According to a recent report by the prevalence of BTB in Ethiopia slaughtered cattle based on postmortem inspection was recorded as a total of 3322 cattle, $86.6 \%(2876 / 3322)$ male, $13.4 \% \quad(446 / 3322)$ female, $94.1 \% \quad(3094 / 3322)$ indigenous zebu breeds, $4.2 \%$ (140/3322) cross breeds and $2.7 \%(88 / 3322)$ pure exotic cattle included for nine years meat inspection recorded. As the report briefly states that of carcass inspected $10.1 \%(337 / 3322)$ at $95 \%$ CI had lesions suggestive of tuberculosis, 20.5\% (69/337) generalized TB and $79.5 \%(268 / 337)$ localized TB [22].

The overall prevalence they recorded on that report was $10.1 \%$ of BTB on five different abattoirs namely: Yeballo abattoir (4.2\%), Awasa abattoir, Adama abattoir Addis Ababa abattoir, and Melge Wondo abattoir. In the present study, the prevalence of BTB by abattoir survey (16.9\%) was comparatively greater than the previous report from Yabello abattoir $(4.2 \%)$. The whole cases faced in this study were suggestive of localized TB since the lesions were found in specific organs and /or tissues [22].

The routine histopathological examination revealed that the majority of the lesions had characteristics microscopic changes, that are well-developed granuloma made by a cluster of macrophages (epithelioid cell, reticuloendothelial cell) surrounding assisted necrosis at the center and the whole mass encircled by fibrous tissue [43]. This finding is consistent with that typical tuberculous lesions granulomas with calcification and multinucleated giant cells of Langerhans type were identified (Figure 2).

The result of this study (Table 5) showed that bovine tuberculosis is important in the pastoral area of Yabello district, as the prevalence and the potential risk of transmission to human is expected to be high due to the habit of consumption of the animal product is rampant. The information obtained from animal owners indicated that a large proportion of the human tuberculosis cases seen in Yabello district might be associated with poor awareness of the transmission and control of BTB from cattle to human, human to cattle interaction and, the consumption behavior of people raw milk in a rural area. This study consistent with, that demonstrated the association of $\mathrm{M}$. tuberculosis and $\mathrm{M}$. bovis causing tuberculosis between humans and cattle. The cattle owned by tuberculous patients had a higher prevalence $(24.3 \%)$ than cattle owned by nontuberculous owners with $8.6 \%$. On the other hand, in Borana, consuming raw meat is a welcome traditional, thus meat may also remain to be another area of concern or threat to be a source of BTB infection [20].

The proportion of EPTB form of human tuberculosis patients ranged from $13.8 \%$ to $19.7 \%$ (mean=13.76\%) over six years study period (Table 4), although it showed fluctuation thought the years (Figure 1). The evident of 87 patients with TB, $63(72 \%)$, and $24(28 \%)$ were diagnosed as pulmonary and extrapulmonary $\mathrm{TB}$, respectively. Of $\mathrm{TB}$ patients about $84 \%(73 / 887)$ were consuming raw milk products. While only $7 \%(6 / 87)$ were consumed boiling milk regularly. The remaining 9\% (8/87) reported that they did not consume milk at all [10].

In rural areas of Ethiopia, most people drink raw milk and do have an extremely close attachment with cattle (Such as sharing shelter) that intensifies the transmission and spread of BTB. Detection of the causal agent of BTB from raw milk confirms the existing problem and the potential risk of the infection in humans. Concerning this, demonstrated that out of 7,138 human patients with tuberculosis $38.4 \%$ were found with extrapulmonary tuberculosis and the proportion of patients with extrapulmonary tuberculosis was significantly associated in patients who have close contact with cattle and in those who frequently used to drink raw milk in particular $[18,19]$.

\section{Conclusion and Recommendations}

Throughout the world, tuberculosis caused by M. bovis is still regarded as a problem for animal and human health is significant in both economic and social terms. Thus, continuous and regular disease surveillance and diagnosis especially in endemic areas where risk factors are mostly present are mandatory. In Ethiopia, the endemic nature of the infections due to $M$. bovis has long been reported and it was found to be the cause of cervical lymphadenitis in humans. This indicates the significance of bovine tuberculosis in between human and cattle. Besides, the existing culture of drinking raw milk and eating raw meat as well as very common close contact of animals with a human in a rural area and being an occupational disease in abattoir workers are the potential risk factors that favor the spreading of infection. In recent years, it has become evident that wildlife has a great role as maintenance hosts of the M. bovis and can play in sustaining the infection in domestic stock. In this study, the trend data collected from Yabello Health Center that TB incidence in the last years has fluctuated thought the year with variation between pulmonary and extra-pulmonary form. Although the incidence still decreasing, taking strict control measures is highly important. Thus, based on the above conclusion, the following recommendations can be forwarded:

1) The abattoir authority should strive a lot to control of back yard and illegal slaughtering practices to minimize unknown infection and spread of BTB in the society;

2) For improvement of management and hygienic practice of pastoral society, awareness should create through education of the public on the potential risk factors of BTB;

3) An immediate and appropriate control program against bovine tuberculosis infection should be designed; 
4) Furthermore, it is highly important to integrate research and disease surveillance programs in between the medical and veterinary institutions, as it helps and simplify the designing of feasible control program against bovine tuberculosis infection and to minimize the zoonotic threat of tuberculosis;

5) Further research should be initiated to assess the wild interface as possible risk factors for the domestic animals by maintaining M. Bovis.

\section{Acknowledgements}

Fist and for most, we would like to praise the heavenly Father for His mercy forever.

Extended thank goes to National Animal Health Diagnostic and Investigation Center (NAHDID) especially, Dr. Mesfine Sahel for his permission to our work in the Institution and Yabello abattoir meat inspector for their help during CIDT test fieldwork and post mortem sample collections respectively.

\section{References}

[1] Michel AL, Muller B, van Helden PD (2010) Mycobacterium bovis at the animal-human interface: A problem, or not? Vet Microbiol 140: 371-381. Link: http://bit.ly/2U8Uq2b.

[2] Malama S, Muma JB, Olea-Popelka F, Mbulo G (2013) Isolation of Mycobacterium Bovis from Human Sputum in Zambia: Public Health and Diagnostic Significance. J Infect Dis Ther 1: 3. Link: http://bit.ly/2RC4fU.

[3] Anon, (2001): World animal health in 2001. Volume 1 and 2 office international des Epizootics (OIE). J. Clerk Maxwell, A Treatise on Electricity and Magnetism, 3rd ed., vol. 2. Oxford: Clarendon, 1892, pp. 68-73.

[4] Ameni G, Tadesse K, Hailu E, Deresse Y, Medhin G., (2010) Transmission of Mycobacterium tuberculosis between farmers and cattle in central Ethiopia. PLos one 8: e76891.

[5] De Lisle G. W., Bengis, R. G., Schmitt S. M. and O'Brien, D. J. (2002): Tuberculosis in free-ranging wildlife detection, diagnosis and management. Rev. Sci. Tech., 21 (2): 317-334.

[6] Phillips, C. J. C., Foster C. R. W., Morris, P. A., and Everson, R. (2003): Review the transmission of Mycobacterium bovis infection to cattle. Res. Vet. Sc., 74: 1-15.

[7] Menzies, F. D., Neill, S. D. (2000): Cattle-to-cattle transmission of bovine tuberculosis. Vet. J., 160 (2): 92-106.

[8] Ameni, G., Wudie, A. and Erkihun, A. (2007): Bovine tuberculosis on small-scale dairy farms in Adama town, central Ethiopia, and farmer awareness of the disease. Rev. Sci. Tech. Off. Int. Epiz., 26 (3): 711-719.

[9] Tschopp R, Schelling E, Hattendorf J, et al. Risk factors of bovine tuberculosis in cattle in rural livestock production systems of Ethiopia. Prev Vet Med. 2009; 89 (3-4): 205-211.

[10] Ameni, G. and Wudie, A. (2003): Preliminary study on bovine tuberculosis in Nazareth Municipality Abattoir of central Ethiopia. Bull. Anim. Helht. prod. Afr., 51: 125-132.
[11] Regassa, A., Medhin, G., and Ameni, G. (2007): Bovine tuberculosis is more prevalent in cattle owned by a farmer with active tuberculosis in Central Ethiopia, Veterinary journal.

[12] Malama S, Muma JB, Godfroid J. A review of tuberculosis at the wildlife livestock-human interface in Zambia. Infect Dis $\begin{array}{llll}\text { Poverty. } & 2013 ; & 2 & \text { (13). }\end{array}$ https://doi.org/10.1186/2049-9957-2-13.

[13] Corbett, E. L., Watt, C. J., Walker, N., Maher, D., Williams, B. G., Raviglione, M. C. and Dye, C. (2003): The growing burden of tuberculosis global trends and interactions with the HIV epidemic. Arch. Intern. Med., 163: 1009-1021.

[14] Ayele, W. Y., Neill, S. D., Zinsstag, J., Weiss, M. G. and Pavlik I. (2004): Bovine tuberculosis is an old disease but a new threat to Africa. Int. J. Tuberc. Lung Dis., 8: 924-937.

[15] Tenguria KR, Khan FN, Quereshi S, et al. Review Article Epidemiological Study of Zoonotic Tuberculosis Complex (ZTBC). World Journal of Science and Technology. 2011; 1: $31-56$

[16] Cleaveland S, Mlengeya T, Kazwala RR, et al. Tuberculosis in Tanzanian wildlife. Journal of Wildlife Diseases. 2005; 41 (2): 446-453.

[17] Girmay G, Pal M, Deneke Y, Weldesilasse G, Equar Y. Prevalence and public health importance of bovine tuberculosis in and around Mekelle town. Ethiopia Int J Livestock Res. 2012; 2: $180-8$.

[18] Zeru F, Romha G, Berhe G, Mamo G, SisayT AG. Prevalence of bovine tuberculosis and assessment of cattle owners' awareness on its public health implication in and around Mekelle, northern Ethiopia. J Vet Med Animal Health. 2014; 6: 160-7.

[19] Anonymous. Project Appraisal document on pastoral community development projects. The World Bank Document. New York, USA; 2003. 114p.

[20] Regassa, A. (2005): Study on Mycobacterium bovis in animals and human in and around Fiche, North Shewa zone, Ethiopia, MSc. thesis, Faculty of Veterinary Medicine, Addis Ababa University, Debre-Zeit, Ethiopia.

[21] Bedane, A. M. (2007): Bovine tuberculosis in cattle slaughtered at Yabello Municipal Abattoir, Southern Ethiopia, DVM thesis, AAU, FVM, Debre Zeit, Ethiopia.

[22] Demelash, B., Inangoalet, F., Oloya, J., Asseged, B., Badaso, M., Yilikal, A. and Skjerve, E. (2008): Prevalence of bovine tuberculosis in Ethiopia slaughter cattle based on post-mortem examination, Norwegian School of Veterinary Science Oslo, Norway.

[23] Agrotec-C-R-G. (1974): Southern Rangelands Livestock Development Project. Imperials Ethiopian Government Livestock and Meat Board. Addis Ababa, Ethiopia, Vol 1-4. K. Elissa, "Title of paper if known," unpublished.

[24] LCBPD, (2007): Let's Contribute for Borana Pastoralist Development Bulletin.

[25] Oba, G. (1998): Assessment of indigenous range management knowledge of the Borana pastoralists of Southern Ethiopian, cooperation with BLPDP/GTZ, OSLO, Norway, 10-18.

[26] Thrusfield. M. (2018). Veterinary Epidemiology $4^{\text {th }}$ ed., Black level Science Ltd Black well publishing Company Editorial Office to Africa. $P p:$ :275-282. 
[27] OIE. Bovine tuberculosis. In: Manual of Diagnostic Tests and Vaccines for Terrestrial Animals. Part 2, Section 2.4. Chapter 2.4.7. World Organization for Animal Health; 2010; pp. 683698.

[28] Ameni, G., Hewinson, G., Aseffa, A., Young, D. and Vordermeier, M. (2008): Appraisal of interpretation criteria for the comparative intradermal tuberculin test for the diagnosis of bovine tuberculosis in Central Ethiopia. Clin. Vacc. Immunol., 15 (8): 1272-1276.

[29] Zerihun, W. (2002): Evaluation of abattoir inspection for the diagnosis of $M$. bovis infection in cattle at Addis Ababa abattoir, DVM Thesis, Faculty of Veterinary Medicine, Debre Zeit, Ethiopia, 27p.

[30] Gracy, J. F. (1986): Meat Hygiene, $8^{\text {th }}$ ed., Baillire-Tindall, London. 350-360.

[31] Jubb, K, V., Kennedy, P. C. and Palmer, N. (1991): Pathology of Domestic Animals $4^{\text {th }}$ ed., 2: 641-652.

[32] Luna, L. G. (1968): Manual of Histological Staining Method of the Armed Forces Institute of Pathology $3{ }^{\text {rd }}$ ed., Dehil.

[33] Asseged, B., Woldesenbet, Z., Yimer, E. and Lemma, E. (2004): Evaluation of abattoir inspection for diagnosis of Mycobacterium bovis infection in cattle at Addis Ababa abattoir. Tropical Animal Health and Production, 36: 537-546.

[34] Shirima, G. M., Kazwala, R. R. and Kambarage, D. M. (2003): Prevalence of bovine tuberculosis in cattle in different farming systems in the Eastern zone of Tanzania. Prev. Vet. Med., 57 (3): 167-172.

[35] Cleave land, S., Shaw, D. J., Mfinanga, S. G., Shirima, G., Kazwala, R. R., Eblate, E. and Sharp, M. (2007): Mycobacterium bovis in rural Tanzania: risk factors for infection in human and cattle populations, 87 (1): 30-43.

[36] Tefera, W., Gezahegne, M., Temesgen, M. and Gobena, A., 2015. Prevalence of bovine tuberculosis in beef feedlot of Borena cattle by using comparative intradermal skin test, Adama, Ethiopia. Ethiopian Veterinary Journal 2016, 20 (2): 17-29.

[37] Teklul, A., Asseged, B., Yimer, E., Gebeyehu, M. and Woldesenbet, Z. (2004): Tuberculous lesions not detected by routine abattoir inspection: The experience of the Hosanna municipal abattoir, Southern Ethiopia. Rev. Sci. Tech., 23 (3): 957-964.
[38] Kathleen, A., Alexander, Evepleydell, Mark. C., Williams, Emilyp, Lane, John, F. C. and Nyange, Anital. Michel, (2002): Mycobacterium tuberculosis: An Emerging Disease of Free-ranging. Wild life emerging infection diseas, 8 (6): 598-601.

[39] Keet, D. F., Kriek, NPJ, Begins, RG, and Michel, A. (2001): Tuberculosis in Kudu in the Kruger National park. Onder stepoort J. vet. res., 68: 225-230.

[40] Tamiru F Hailemariam M, Terfa W. Preliminary study on prevalence of bovine tuberculosis in cattle owned by tuberculosis positive and negative farmers and assessment of zoonotic awareness in Ambo and Toke Kutaye districts, Ethiopia. Journal of Veterinary Medicine and Animal Health. 2013; 5 (10): 288-295.

[41] Regassa, A., Tassew, A., Amenu, K., Megersa, B., Abunna, F., Mekibib, B., Macrotty, T. and Ameni, G., 2010. A cross-sectional study on bovine tuberculosis in Hawassa town and its surroundings, Southern Ethiopia. Trop. Anim. Health Prod., 42, 915- 920.

[42] Biffa, D., Inangolet, F., Bogale, A., Oloya, J., Djonne, B. and Skjerve, E., 2011. Risk factors associated with prevalence of tuberculosis-like lesions and associated mycobacteria in cattle slaughtered at public and export abattoirs in Ethiopia. Trop. Anim. Health Prod., 43, 529-538.

[43] Taddesse, A. (2009): Preliminary study on Bovine tuberculosis in Western Ethiopia at Nekemte Municipal Abattoir, DVM thesis, FVM, Mekelle, Ethiopia.

[44] Whipple, D. L., Bolin, C. A. and Miller, J. M. (1996): Distribution of lesions in Cattle infected with Mycobacterium bovis. J Vet. Diagn. Invest., 8: 351-354.

[45] Miliano-suazo, F., Salmar, M. D., Ramirez, C., Payear, J. B., Rhyan, J. C. and Santilan, M. (2000): Identification of TB in cattle slaughtered in Mexico AM. J. Vet. Res., 1 (1): 68-89.

[46] Habtamu, T. (2006): A cross-sectional study on Bovine Tuberculosis in Jinka Municipal Abattoir, DVM thesis, Addis Ababa University, Faculty of Veterinary Medicine, Deibre Zeit, Ethiopia.

[47] D. Tamiru F Hailemariam M, Terfa W. Preliminary study on prevalence of bovine tuberculosis in cattle owned by tuberculosis positive and negative farmers and assessment of zoonotic awareness in Ambo and Toke Kutaye districts, Ethiopia. Journal of Veterinary Medicine and Animal Health. 2013; 5 (10): 288-295. 